This manuscript is contextually identical with the following published paper:

Várbíró, G., Padisák, J., Nagy-László, Z. et al. Hydrobiologia (2018).

The original published PDF available in this website:

https://doi.org/10.1007/s10750-017-3447-1

\title{
How length of light exposure shapes the development of riverine algal biomass in temperate rivers?
}

Várbíró G ${ }^{\mathrm{a}, \mathrm{b}}$, Padisák J $\mathrm{J}^{\mathrm{c}, \mathrm{d}}$, Nagy László $\mathrm{Zs}^{\mathrm{c}}$, Abonyi A ${ }^{\mathrm{a}}$, Stanković $\mathrm{I}^{\mathrm{e}}$, Gligora Udovič $\mathrm{M}^{\mathrm{f}}$, BBéres $\mathrm{V}^{\mathrm{b}}$ and Borics G. ${ }^{\mathrm{a}, \mathrm{b}}$

${ }^{a}$ MTA Centre for Ecological Research, Danube Research Institute Department of Tisza River Research, H-4026 Debrecen, Bem tér 18/C, Hungary varbiro.gabor@okologia.mta.hu

${ }^{b}$ MTA Centre for Ecological Research, GINOP Sustainable Ecosystems Group, H-8237 Tihany, Klebensberg Kuno u. 3, Hungary;

${ }^{c}$ University of Pannonia, Department of Limnology H-8200 Veszprém, Egyetem Str. 10, Hungary

${ }^{d}$ MTA-PE Limnoecology Research Group, H-8200 Veszprém, Egyetem Str. 10, Hungary

${ }^{e}$ Hrvatske vode, Central Water Management Laboratory, Ulica grada Vukovara 220, 10000 Zagreb, Croatia

${ }^{f}$ University of Zagreb, Faculty of Science, Department of Biology, Rooseveltov trg 6, HR10000 Zagreb, Croatia 


\begin{abstract}
The impact of cumulative daily solar radiation (CDSR) on the biomass of river phytoplankton (Chl- $a$ ) in the growing season was studied using a large dataset of rivers in the Carpathian Basin. The amount of solar radiation was cumulated over the range of 1-60 days. The CDSRChl- $a$ relationship could be described by linear regression and appeared to be significant for almost all watercourses with the exception of rivers with short water residence time. To determine the most relevant time period of CDRS impacting phytoplankton biomass, the slopes of regressions were plotted against the accumulating number of days of light exposure (1-60). Two characteristic shapes were obtained: unimodal for rivers with hard substrate and steady increase for lowland rivers with fine substrate. In both cases, there is an increasing tendency in the slope values with water residence time (WRT). It was demonstrated that CDSR has a pronounced impact on river phytoplankton biomass even in cases when WRT was shorter than the cumulated solar radiation period. These results indicate that development of phytoplankton within the river channel is a complex process in which meroplankton dynamics may have significant impacts. Our results have two implications: First, CDSR cannot be neglected in predictive modelling of riverine phytoplankton biomass. Second, climate models forecast increased drought with subsequently increased CDSR in several regions globally, which may trigger a rise in phytoplankton biomass in light-limited rivers with high nutrient concentrations.
\end{abstract}

Keywords: cumulative daily solar radiation, phytoplankton, residence time

\title{
Introduction
}

Phytoplankton produces the majority of organic matter in most of the aquatic ecosystems. This group represents the first level of the pelagic food chain not only in the oceans and 
inland standing waters, but also in the middle and lower sections of large rivers (Descy and Gosselain, 1994; Schmidt, 1994; Stanković et al., 2012). A significant amount of knowledge has been accumulated with respect to phytoplankton dynamics and ecology in lacustrine environments. Several models were published on the phytoplankton succession (Sommer et al., 1986, Sommer, 1989), on the development of phytoplankton biomass (reviewed in Phillips et al., 2008), or on mechanisms that drive phytoplankton diversity (Hutchinson, 1961; Roy and Chattopadhyay, 2007). Much less information is available about the ecology of phytoplankton in riverine ecosystems. The drastic hydromorphological alterations in the floodplains, and the fact that rivers became the main recipients of wastewaters hindered the study of natural watercourses. However, there are some general features of the riverine phytoplankton, which have been revealed for several rivers in the temperate zone.

Contrary to lakes where nitrogen and phosphorus are considered to be the primary limiting factors for algal growth, nutrients are available in high excess in most rivers and their concentrations hardly limit algal development (Reynolds and Descy, 1996). In rivers, an important limiting factor is water residence time (WRT) (Soballe and Kimmel, 1987). Depending on the phytoplankton growth-loss balance in the water bodies, WRT can affect either positively or negatively the growth of planktic assemblages (Lucas et al., 2009). In upper river segments, where WRT is not sufficient for the development of phytoplankton (Lucas et al., 2009), planktic assemblages consist primarily of suspended benthic elements (mostly pennate diatoms) entrained from various surfaces of the river-bed (Abonyi et al., 2012; Bolgovics et al., 2015, 2017; Várbíró et. al., 2007). This so-called rhithroplankton is continuously enriched with euplanktonic species further downstream. As a result, the middle and lower sections of large rivers are characterised by high-biomass of euplanktonic phytoplankton assemblages (Várbíró et al., 2007). High level of nutrients and long WRT, 
however, provide necessary but not sufficient conditions for the development of phytoplankton in watercourses (Lucas et al., 2009).

Rivers are highly variable systems, where the environmental characteristics are subjected to extreme fluctuations (Bukaveckas et al., 2011). From these environmental features, light conditions are among the most important regulatory factors of phytoplankton in rivers (Bukaveckas et al., 2011; Ochs et al., 2013). Depending on the concentration of suspended solids, the light perceived by the phytoplankton may range from full sunlight to complete darkness, and the rate of primary production can be limited by the available Photosynthetically Active Radiation (PAR). The ratio between euphotic $\left(Z_{\mathrm{eu}}\right)$ and mixing depth $\left(Z_{\text {mix }}\right)$ determines the amount of irradiance encountered by a phytoplankton cell (Talling, 1957, 1971). Critical values of $Z_{\text {eu }} / Z_{\text {mix }}$ ratio vary between 0.2 and 0.35 (Reynolds, 1984; Cole et al., 1992). Below these values the respiratory carbon use of phytoplankton exceeds the rate of photosynthetic carbon supply. Despite the presence of viable phytoplankton assemblages in water column, net primary production may decrease if phytoplankters cannot spend time enough in the in the euphotic zone (Ochs et al., 2013). Thus, phytoplankton might eventually disappear from the water column.

While a number of field and laboratory studies focused on the relationship between the underwater light climate and phytoplankton growth (Ochs et al., 2013), much less attention has been paid to the role of light intensity and duration to the water surface. The upper surface of a continuous sheet of deep clouds can reflect $\sim 70 \%$ of the total solar radiation and can absorb an additional $\sim 20 \%$ (Kirk, 2011). Thus, it is possible that due to the weather conditions nearly ten times differences characterize the daily incident solar irradiance. This should have a pronounced effect on the production and biomass of phytoplankton. Long-term monitoring of surface waters and meteorological stations provide a huge amount of data on chlorophyll- $a$ 
$(\mathrm{Chl}-a)$, and on the number of sunny hours. Coupling these databases provides a potentially powerful method to study the relationship between light exposure and phytoplankton biomass.

The aim of the present study was to assess the role of sunny hours (as a proxy of solar irradiance) in the development of phytoplankton biomass (Chl- $a$ ) in temperate rivers.

We hypothesised (i) that solar irradiance has a significant effect on river phytoplankton, and (ii) the river characteristics has a pronounced influence on the relationship between phytoplankton biomass and light exposure.

\section{Materials and methods}

\section{Studied rivers}

Growing season (May-September) sestonic Chl- $a$ data of rivers in the Carpathian basin for the period of 1992-2010 were used for the analyses. Data were provided by the Hungarian Water Quality Monitoring Database. The database contained Chl- $a$ data of 52 rivers from 103 sampling sites (Fig 1). Before the analyses, several screening steps were performed. First, the small lowland macrophyte dominated streams were excluded. In the second step, all rivers, where sporadic extreme high Chl- $a$ values indicated because of the obvious impact of instream or off-river reservoirs, were ruled out. Finally, data were screened to exclude those sites, where short water residence time (WRT $<5$ days) was coupled with high mean phytoplankton biomass $\left(\mathrm{Chl}-a>30 \mu \mathrm{gl}^{-1}\right)$ which indicated again an impact of off-river reservoirs or ponds. Theoretical water residence time was calculated as a function of drainage area $\left(\mathrm{Ad}, \mathrm{km}^{2}\right)$ and water discharge $\left(\mathrm{Q}, \mathrm{m}^{3} \mathrm{~s}^{-1}\right)$ using the equation $\mathrm{WRT}=0.08 \times \mathrm{Ad}^{0.6} \times \mathrm{Q}^{-0.1}$ (Soballe and Kimmel, 1987) for each sampling sites and for on each sampling event. Thus, the final dataset consisted of 39 rivers and 88 sites with 13044 sampling events. The relevant hydrological and morphological parameters of the rivers are shown in Electronic 
Supplementary Material(ESM) Table 1. Chl- $a$ measurements followed the hot-ethanol extraction method (MSZ ISO 10260:1993).

\section{Light exposure}

As a surrogate measure of light exposure, the sum of daily solar radiation (DSR) values was used (May to September). The dataset included sunshine hours for Budapest and was provided by the Hungarian Meteorological Service. The regional differences of the global radiation in Hungary are smaller than 10\% (Szász, 1997). This value is much smaller than the value of the possible daily variation and therefore this simplification hardly affects the results to be obtained.

DSR was derived from sunshine hours in each day, applying Angstrom's formula (1924) with coefficients applicable to Hungary (Szász, 1997):

$$
\operatorname{DSR}=\operatorname{DSR}_{0}\left(0.28+0.72 \frac{s}{s_{m}}\right)
$$

where

DSR: daily solar radiation $\left(\mathrm{MJ} \mathrm{m}^{-2}\right)$

$\mathrm{DSR}_{0}$ : Monthly theoretically possible global radiation on horizontal surface in Hungary (MJ $\left.\mathrm{m}^{-2}\right)$

S: measured daily values of the bright sunshine hours for the given day

$\mathrm{S}_{\mathrm{m}}$ : maximum possible sunshine hours for the given date (monthly mean values were applied) The light exposure matrix contained 60 cumulative DSR (CDSR) values for one to sixty days period prior to each sampling date.

\section{Data analysis}

Log transformed Chl- $a$ values were plotted against the log CDSR values cumulated for each of the exposure periods and at each sample site. The period ranged from one day to sixty days, 
the building of the model matrix is described in Table 1. General linear model was used with the following equation to assess the effect of cumulated DSR values on Chl- $a$.

$$
\log (\mathrm{Chl}-a)=\propto+\beta \log \left(\operatorname{CDSR}_{i}\right)+e
$$

where

Chl- $a$ : Chlorophyll-a content in $\mu \mathrm{gL}^{-1}$

$\operatorname{CDSR}_{\mathrm{i}}$ : the cumulative energy on the $\mathrm{i}^{\text {th }}$ day

$\beta:$ slope

$\alpha$ : intercept

e: residuals

The coefficients of determination (R2), the slope ( $\beta$ ) and level of significance (p-we set our significance level at 0.05 ) were used to determine the overall fit of the models.

Since sixty models were constructed for each sampling site, altogether $5280(60 \times 88)$ model results were evaluated. In all cases, the $\mathrm{R}^{2}$ values were plotted against the periods' lengths. The maxima of these curves indicate the length of light exposure having the highest explained variance of phytoplankton biomass.

Data analyses were performed using R program package (R Development Core Team, 2016).

\section{Results}

Phytoplankton biomass varied considerably at each sample site (ESM Table 1). Differences were moderate in small streams, but exceeded two orders of magnitude in large lowland rivers. DSR values varied between 1.6 and $32 \mathrm{MJ}$ m-2 day-1. CDSR values showed approximately five times differences across the whole range of light exposure days Fig 2. 
In most rivers, Chl-a / CDSR relationship was significant and could be described by linear regression model. Exceptions were those few watercourses where the WRT was smaller than 6 days. In the majority of cases, the significant relationship was characteristic only for a certain range of the 60-day light exposure period. However, the fact that the slope of the regression line is significantly different from zero does not necessarily mean that phytoplankton biomass considerably determined by the cumulated light exposure. Therefore, the slopes of regressions were plotted against the days of light exposure - (DLE) (Fig 3). Based on the shapes of the curves two distinct patterns could be distinguished; monotonously increasing and hump shaped (Fig $3 \mathrm{a}-\mathrm{d}$ ). In case of lower sections of the rivers (Fig $3 \mathrm{~b}$ and c), the observed steady increase in slope values indicates that pronounced increment of phytoplankton biomass needs longer light exposure. In contrast, hump-shaped relationship (Fig 3 d) occurred in the upper sections of the rivers, which implies that significant increase in phytoplankton biomass could be expected at shorter light exposure. The slope of the regressions i.e. dependence of phytoplankton biomass on the solar radiation was also influenced by water residence time (Fig 4 a-d).

In river Danube, the peak of the hump-shaped curve shifted towards the longer light exposure range (30-40 days), slightly flattened in the lower river sections (higher values of WRT) and had a maximum slope value of $\beta=1.8$ (Fig 4 a).

In Tisza river, the steady increase of slope values with DLE could also be observed, but it showed a bimodal character along the WRT with peaks reaching the slope value of $\beta \sim 3$ (Fig $4 b)$.

The highest slope values characterised the lowland rivers with fine substrate. In this river group the values showed steady increase both with the DLE and WRT and attained the $\beta=5$ values (Fig 4c). 
Increment of phytoplankton biomass in rhitral rivers with coarse substrate was less pronounced. The slope values showed unimodal relationship both with the light exposure and WRT. Maximum slope values were only 1.5 and fell in the range of 10-30 DLE and 12-20 days of WRT (Fig 4d).

The explained variances of the applied linear regression models were closely related to the slope values (Fig 5a-d). Highest $\mathrm{R}^{2}$ values characterised the lowland streams with fine substrate. In this river group the explained variance attained the 0.35 value. The river Tisza and the lower sections of Danube also belong to this category. Although the explained variances of the models were smaller in case of rivers with coarse substrates, these values were reasonably high $\left(\mathrm{R}^{2}=0.2\right)$ for several sites.

\section{Discussion}

Solar radiation appeared to be a strong predictor of phytoplankton biomass in most rivers. However, depending on the type of water body solar radiation accounted for about $10-95 \%$ of the heat input into surface waters (Birge, 1916; Platts, 1983). Water temperature has a profound influence on the photosynthetic activity of algae and studying the processes on a longer time scale (i.e. from January to July in temperate region) it could be very difficult to distinguish the impacts of temperature on the phytoplankton biomass from that of the solar radiation. The five-month time frame applied in this study covered the warmest period of the years when water temperature is relatively constant (range of changes $\sim 5-7^{\circ} \mathrm{C}$ at site level), while daily variation of DSR values occasionally reached twenty-fold differences (1.6 -32 MJ $\mathrm{m}^{-2}$ day $^{-1}$ ) and variation of DSR values cumulated for the maximal 60-day long period still attained a five-fold difference.

In some several watercourses no significant relationships between DSR and Chl- $a$ was found. In these cases, however, short water residence time ( $<6$ days) explained the non-significant 
relationships. Interestingly, for several rivers we observed that the highest slope and $\mathrm{R}^{2}$ values fell in a range of the light exposure gradient (DLE) where the numbers of light exposure days exceeded the WRT of the given watercourse. This contradiction in these rivers can be explained by considering the composition and recruitment of phytoplankton in rhitral rivers. Phytoplankton of rhitral rivers (rivers with low WRT values and coarse substrates) consists primarily on tychoplanktonic elements, i.e. benthic taxa that entrained to the plankton after detached from the substrates (Bolgovics et al., 2015, 2017). Thus, phytoplankton of rhithral rivers strongly depends on the composition and biomass of the benthic algae living in the various habitats of the river bed and the current velocity has to be sufficient to keep benthic organisms in suspension. Since the development of mature phytobenthos needs longer time, typically more than four weeks (Lengyel et al., 2015, Tapolczai et al., 2016), it is not surprising that the number of light exposure days belonging to the highest slope values is higher than WRT of the given rhithral river.

In lowland rivers where both the slopes and $\mathrm{R}^{2}$ values showed steady increase with the days of DSR, the number of days belonging to the highest slope and $\mathrm{R}^{2}$ values (60 days) also exceeded the WRT of the rivers ( 16-23 days). In these rivers, high-biomass/low-diversity phytoplankton prevails (Borics et al., 2014) and is dominated by medium-sized centric diatoms like Cyclotella meneghiniana Kützing (Várbíró et al., 2007). These taxa are considered as euplanktonic elements, i.e. species that live exclusively in the pelagial. However, Istvánovics and Honti (2011) demonstrated that in slow-flowing rivers these diatoms with high sedimentation rates settle to the bottom and can have a prolonged benthic residence. This practically means that these taxa can exhibit meroplanctonic life histories in this kind of rivers. Due to sufficiently strong hydraulic forces they can entrain into the suspension again. This so called benthic retention hypothesis argues that residence time of 
large-celled diatoms exceeds that of the advecting, truly planktic algae. This explicitly explains the "days of CDSR > WRT" controversy.

Istvánovics and Honti (2011) described this meroplankton dynamics for the River Szamos (Hungary), which was also part of our study and had the highest slope and $\mathrm{R}^{2}$ values. This meroplankton dynamic enables the development of high phytoplankton biomass (maximum value of Chl- $a$ in the River Szamos was $518 \mu \mathrm{gl}^{-1}$ in our database), which, considering an approximately $1 \mathrm{~m}$ mean depth for the river in the summer period, is very close to the theoretical maximum of the depth integrated Chl- $a$ content of surface waters $\left(600 \mathrm{mg} \mathrm{m}^{-2}\right)$ estimated by Reynolds (2006) and measured occasionally in hypereutrophic ponds (Borics et al., 2000).

The impact of the two large tributaries (Szamos and Maros) on the phytoplankton of the Tisza can be clearly seen in Fig 4b, whereas the bimodal character of the slope values were unequivocally due to these large inflows.

The curves of slope values showed unimodal distribution in case of the Danube with a shifting peak towards the longer light exposure range. This pattern is consistent with the typological differences that can be observed along the $417 \mathrm{~km}$ Hungarian section of the river. In the upper river segment, the channel is composed by coarse sediment (cobbles and gravel) while the lower river segment is covered with is sandy. Parallel with this shift in river type, biological elements including macroinvertebrates (Graf et al., 2008), fish (Erős et al., 2016) and planktic algae (Dokulil and Donabaum, 2014) also showed compositional and/or quantitative changes. The position of the peaks in the upper river segment of the Danube fall between 7-12 days (Fig 3a), which is surprisingly shorter than the range that characterised the small streams and rhithral rivers (12-25 days) (Fig 3d). Sedimentation of algae in the reservoir might have a pronounced influence on the composition and biomass of the phytoplankton, which modifies its response to the CDSR. Profiles of the curves belonging to the lower sections of Danube 
became similar to that of the lowland potamal rivers.(Fig 4a,c). However, declines of the curves in the CDSR $>42$ days range indicates that the meroplankton dynamics, which must be responsible for the high slope values in lowland rivers with fine sediment even in case of long light exposure (Fig 4c) does not play significant role in the River Danube. Although meroplankton dynamics occurs in the shallow part of the Danube's riverbed but its importance is much smaller compared to the overwhelming dominance of potamoplakton.

Modelling of river phytoplankton biomass is a challenging task. Nutrients, suspended particles, turbidity, residence time and catchment area, are the most frequently used variables in empirical models to predict biomass of algae or its proxy, the sestonic Chl- $a$ (Sterner et al., 1996). Fluctuation of discharge, the impacts of impoundments and the various river influents result in low explanatory power of the models. What we have learned from the majority of studies dealing with eutrophication that nutrients are essential for algal growth and the nutrient-Chl- $a$ relationship is nonlinear (Phillips et al., 2008). This relationship can be highly significant not only for lakes but also for rivers (Van Nieuwenhuyse and Jones, 1996). Nevertheless, as it was shown by the aforementioned authors who studied the relationship in the 5-1000 $\mu \mathrm{gl}^{-1} \mathrm{TP}$ range, that the strong relationship can only be demonstrated if the TP gradient is large. In the eutrophic range where TP highly exceeds $100 \mu \mathrm{gl}^{-1}$, the TP- Chl- $a$ relationship is almost asymptotic both for lakes (Borics et al., 2014; Phillips et al., 2008) and rivers (Van Nieuwenhuyse and Jones, 1996), which makes the adequate modelling of phytoplankton growth really difficult. A number of studies emphasised the role of light in the growth of river phytoplankton and proposed to use it in predictive models (Descy et al., 1987; Descy and Gosselain, 1994; Reynolds et al., 2004). There are many ways of using solar radiation in the models. The fact that occasionally negative relationship was found between solar radiation and river phytoplankton biomass (Whitehead et al., 1997) highlights the need 
of more thorough examination of this issue. The importance of our results is that they are the first to show that CDSR might have pronounced influence on the riverine phytoplankton biomass, and this influence strongly depends on the type of the watercourse and the length of light exposure. It could be important to mention that even if the ratio Zeu/Zmix is low, phytoplankton might not disappear from the water, and might even accumulate, if there are external sources of phytoplankton to the system (eg. supplements from wetlands or lakes). In cases when the CDSR - Chl- $a$ relationship was significant, the explained variance of the regression models varied between 0.03 and 0.35 . Highest values were obtained for the large highly eutrophic lowland rivers with fine sediments. Since phytoplankton is constrained by several regulatory factors among which many are difficult to measure, or not measured routinely at all, solar radiation could be the most relevant explanatory variable that cannot be neglected in future predictive modelling of riverine phytoplankton biomass.

The other important message of our study is that the future changes in river phytoplankton biomass can be affected by global warming. One of the important consequences of the global warming for the mid-latitude continents is the decline in the average summer rainfall (Rowell and Jones, 2006; Rowell, 2009). This potentially means increased aridity, lower cloudiness (Dai, 2011) and higher air temperature (Desortová and Punčocháŕ, 2011). These altered conditions therefore are expected to contribute to the development of high phytoplankton biomass in rivers and increase the risk of critical water quality changes.

\section{Conclusions}

Our results demonstrate that cumulative daily solar radiation (CDSR) is a crucial factor affecting the river phytoplankton biomass. It was also shown that different river types respond in a diverse way to solar radiation, both in terms of the increase rate (slope of linear regression models) and in terms of the variance explained. Because of the strength of the 
relationship between CDSR and Chl- $a$, irradiance cannot be neglected in empirical models predicting phytoplankton biomass especially in light limited eutrophic rivers. Global warming (GW) alters the Earth's hydrological processes in various ways. Consequences of the increased river runoff for catchment phosphorus are well documented in the literature. Through the increased nutrient load, global warming acts on the riverine phytoplankton indirectly. However, our study demonstrated that GW may have a more proximate effect on river phytoplankton biomass. The increased solar radiation expected in many regions of the Earth has a direct, pronounced impact on river phytoplankton biomass. Therefore, it has to be considered in future predictive modelling of primary producers in riverine ecosystems, with implications for the water quality management.

\section{Acknowledgements}

Authors are financially supported by the GINOP-2.3.2-15-2016-00019 project and by the MTA Postdoctoral Research Program (PD-019/2016). Partial support was provided by the Hungarian National Research, Development and Innovation Office (NKFIH K-120595).

\section{References}

Abonyi, A., M. Leitão, I. Stanković, G. Borics, G. Várbíró \& J. Padisák 2014. A large river (River Loire, France) survey to compare phytoplankton functional approaches: Do they display river zones in similar ways? Ecological Indicators 46: 11-22.

Angstrom, A., 1924. Solar and terrestrial radiation. Quarterly Journal of the Royal Meteorological Society 50: 121-126.

Birge, E.A., 1916. The work of the wind in warming a lake. Transactions of the Wisconsin Academy of Sciences, Arts, and Letters 18:341-391. 
Bolgovics, Á., Ács, É., Várbíró, G., Kiss, K.T., Lukács, B.A. \& Borics, G., 2015. Diatom composition of the rheoplankton in a rhithral river system. Acta Botanica Croatica 74: 303-316.

Bolgovics, Á., G. Várbíró, É. Ács, Z. Trábert, K.T. Kiss, V. Pozderka, J. Görgényi, P. Boda, B.A. Lukács, Zs. Nagy-László, A. Abonyi \& G. Borics 2017. Phytoplankton of rhithral rivers: its origin, diversity and possible use for quality-assessment. Ecological Indicators 81: $587-596$

Borics, G., J. Görgényi, I. Grigorszky, Zs. László-Nagy, B. Tóthmérész, E. Krasznai \& G. Várbíró, 2014. The role of phytoplankton diversity metrics in shallow lake and river quality assessment. Ecological Indicators 45: 28-36.

Borics, G., I. Grigorszky, S. Szabó \& J. Padisák 2000. Phytoplankton associations in a small hypertrophic fishpond in East Hungary during a change from bottom-up to top-down control. In The Trophic Spectrum Revisited, Springer Netherlands, 79-90.

Bukaveckas, P.A., A. MacDonald, A. Aufdenkampe, J.H. Chick, J.E. Havel, R. Schultz, T.R. Angradi, D.W. Bolgrien, T.M. Jicha \& D. Taylor 2011. Phytoplankton abundance and contributions to suspended particulate matter in the Ohio, Upper Mississippi and Missouri Rivers. Aquatic Sciences 73, 419-436.

Cole J.J., N.F. Caraco \& B.L. Peierls, 1992. Can phytoplankton maintain a positive carbon balance in a turbid freshwater, tidal estuary? Limnology and Oceanography 37, 16081617.

Dai, A. 2011. Drought under global warming: a review. WIREs Climate Change 2: 45-65.

Descy, J.P. \& V. Gosselain, 1994. Development and ecological importance of phytoplankton in a large lowland river (River Meuse, Belgium). In Phytoplankton in Turbid Environments: Rivers and Shallow Lakes, Springer Netherlands, 139-155. 
Descy, J.P., P. Servais, J.S. Smitz, G. Billen \& E. Everbecq 1987. Phytoplankton biomass and production in the River Meuse (Belgium). Water Research 21: 1557-1566.

Desortová, B. \& P. Punčocháŕ, 2011. Variability of phytoplankton biomass in a lowland river: response to climate conditions. Limnologica - Ecology and Management of Inland Waters 41: 160-166.

Dokulil, M.T. \& U. Donabaum, 2014. Phytoplankton of the Danube river: Composition and long-term dynamics. Acta Zoologica Bulgarica 7: 147-152.

Erős, T., V. Bammer, Á.I. György, L. Pehlivanov, M. Schabuss, H. Zornig, A. Weiperth \& Z. Szalóky, 2016. Typology of a Great River Using Fish Assemblages: Implications for the Bioassessment of the Danube River. River Research and Applications 33: 37-49.

Graf, W., B. Csányi, P. Leitner, M. Paunovic, G. Chiriac, I. Stubauer, T. Ofenböck \& F. Wagner, 2008. Macroinvertebrate. In: I. Liška, F. Wagner, J. Slobodnik, Joint Danube Survey 2 - Final Scientific Report, ICPDR - International Commission for The Protection of The Danube River, Vienna, 41-47.

Hutchinson, G.E., 1961. The paradox of the plankton. The American Naturalist 95: 137-145. Istvánovics, V. \& M. Honti, 2011. Phytoplankton growth in three rivers: The role of meroplankton and the benthic retention hypothesis. Limnology and Oceanography 56: $1439-1452$.

Kirk, J.T., 1985. Light and Photosynthesis in Aquatic Ecosystems. Cambridge University Press. Cambridge. 401.

Lengyel. E., J. Padisák \& C. Stenger-Kovács, 2015. Establishment of equilibrium states and effect of disturbances on benthic diatom assemblages of the Torna-stream, Hungary. Hydrobiologia 750: 43-56 750: 43-56. 
Lucas, L.V., J.K. Thompson \& L.R. Brown, 2009. Why are diverse relationships observed between phytoplankton biomass and transport time? Limnology and Oceanography 54: 381-390.

MSZ ISO 10260:1993 Water quality. Measurement of biochemical parameters. Spectrometric determination of the chlorophyll-a concentration.

Ochs, C.A., O. Pongruktham \& P.V. Zimba, 2013. Darkness at the break of noon: Phytoplankton production in the Lower Mississippi River. Limnology and Oceanography 58: 555-568.

Phillips, G., O.P. Pietiläinen, L. Carvalho, A. Solimini, A.L. Solheim \& A.C. Cardoso, 2008. Chlorophyll-nutrient relationships of different lake types using a large European dataset. Aquatic Ecology 42: 213-226.

Platts, W.S., 1983. Vegetation requirements for fisheries habitats. USDA Forest Service, General Technical Report INT, 157.

Reynolds, C.S., 1984. The Ecology of Freshwater Phytoplankton. Cambridge University Press: Cambridge Reynolds,

Reynolds, C., A. Elliott \& T. Irish, 2004. Modelling the dynamics of phytoplankton with the needs of the end user in mind. In Freshwater Forum. 23: 38-47

Reynolds, C.S. 2006. The ecology of phytoplankton. Cambridge University Press.

Reynolds, CS. \& J.P. Descy, 1996. The production, biomass and structure of phytoplankton in large rivers. Archiv für Hydrobiologie, Supplement Large Rivers 113: 161-187

R Core Team, 2016. R: A language and environment for statistical computing. R Foundation for Statistical Computing, Vienna, Austria. URL https://www.R-project.org/.

Rowell, D.P. \& R.G. Jones, 2006. Causes and uncertainty of future summer drying over Europe. Climate Dynamics 27: 281-299. 
Rowell, D.P. 2009. Projected midlatitude continental summer drying: North America versus Europe. Journal of Climate 22: 2813-2833.

Roy, S. \& J. Chattopadhyay, 2007. Towards a resolution of 'the paradox of the plankton': A brief overview of the proposed mechanisms. Ecological Complexity 4: 26-33.

Schmidt, A. 1994. Main characteristics of the phytoplankton of the Southern Hungarian section of the River Danube. In Phytoplankton in Turbid Environments: Rivers and Shallow Lakes, Springer Netherlands, 97-108.

Soballe, D.M. \& B.L. Kimmel, 1987. A large- scale comparison of factors influencing phytoplankton abundance in rivers, lakes, and impoundments. Ecology 68: 1943-1954.

Sommer, U. 1989. The role of competition for resources in phytoplankton succession. In Plankton Ecology, Springer Berlin Heidelberg, 57-106.

Sommer, U., Z.M. Gliwicz, W. Lampert \& A. Duncan, 1986. The PEG-model of seasonal succession of planktonic events in fresh waters. Archiv für Hydrobiologie 106: 433-471.

Stanković, I., T. Vlahović, M.G. Udovič, G. Várbíró \& G. Borics, 2012. Phytoplankton functional and morpho-functional approach in large floodplain rivers. Hydrobiologia 698: $217-231$.

Sterner, R., S.S. Kilham, F.A. Johnson, R.W. Winner, T. Keeling, R. Yeager \& M.P. Farrell, 1996. Factors regulating phytoplankton and zooplankton biomass in temperate rivers. Limnology and Oceanography 41: 1572-1577.

Szász, G. 1997. Meteorológia - Mezőgazdasági Kiadó, Budapest, 267-280.

Talling, J.F. 1957. The phytoplankton population as a compound photosynthetic system. New Phytologist 56: 133-149.

Talling, J.F. 1971. The underwater light climate as a controlling factor in the production ecology of freshwater phytoplankton. Verhandlungen des Internationalen Verein Limnologie 19: 214-243. 
Tapolczai, K., A. Bouchez, Cs. Stenger-Kovács, J. Padisák \& F. Rimet, 2016. Trait-based ecological classifications for benthic algae: review and perspectives. Hydrobiologia 776: $1-17$.

Van Nieuwenhuyse, E.E. \& J.R. Jones, 1996. Phosphorus chlorophyll relationship in temperate streams and its variation with stream catchment area. Canadian Journal of Fisheries and Aquatic Sciences 53: 99-105.

Várbíró, G., É. Ács, G. Borics, K. Érces, G. Fehér, I. Grigorszky, T. Japport, G. Kocsis, E. Krasznai,K. Nagy, Zs. Nagy-László \& Zs. Pilinszky, 2007. Use of Self-Organizing Maps (SOM) for characterization of riverine phytoplankton associations in Hungary. Archiv für Hydrobiologie 17: 383-394.

Whitehead, P.G., A. Howard \& C. Arulmani, 1997. Modelling algal growth and transport in rivers: a comparison of time series analysis, dynamic mass balance and neural network techniques. Hydrobiologia 349: 39-46.

\section{Legends for tables and figures}

Table 1. Building of the site level matrix used for studying the cumulative daily solar radiation $(\mathrm{CDSR})-\mathrm{Chl}-a$ relationships

Electronic Supplementary Material Table 1. List of sampling sites and descriptive statistics of characteristic physical and chemical parameters 
Fig. 1. Distribution of the sampling sites in the Carpathian basin. Larger black dots refer to the higher maximum slope values.

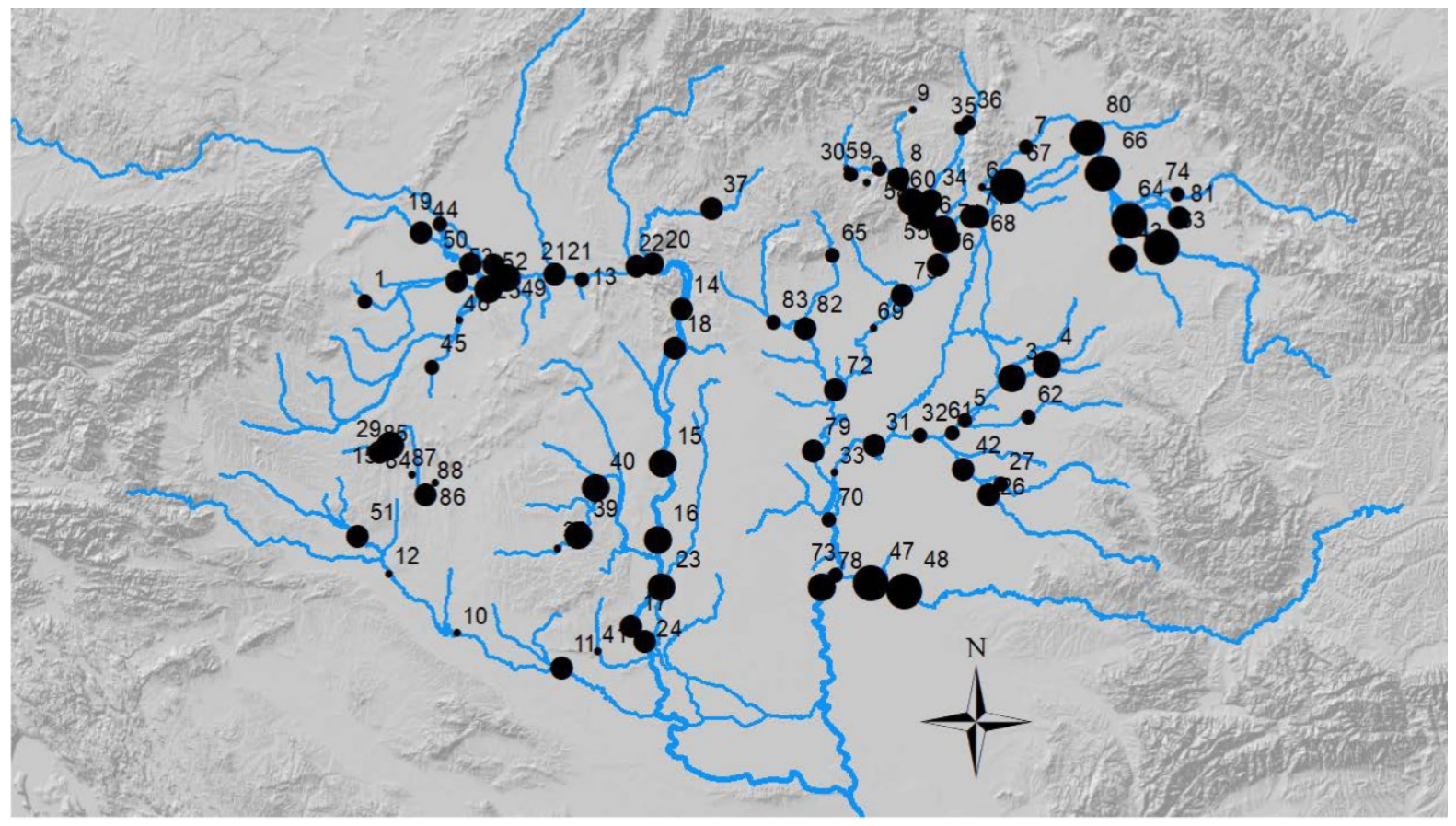

Fig. 2. The range of cumulative daily solar radiation (CDSR in $\mathrm{MJ} \mathrm{m}^{-2}$ ) in the range of time periods studied (1-60 days). The grey areas represent the minimum to maximum values occurred in the database for a given day.

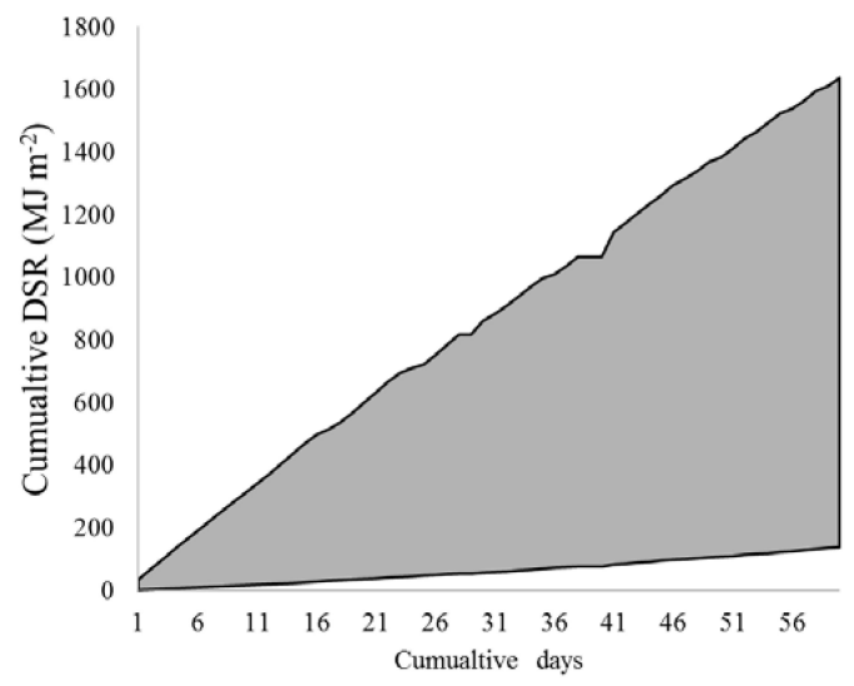


Fig. 3. Line plots illustrating the relationship between the estimated linear slopes for Chl- $a$ regressed against CDSR and number of days contributing to the CDSR: (a) Danube, (b) Tisza, (c) Potamal, and (d) Rhitral. The lines refer to different sampling sites.
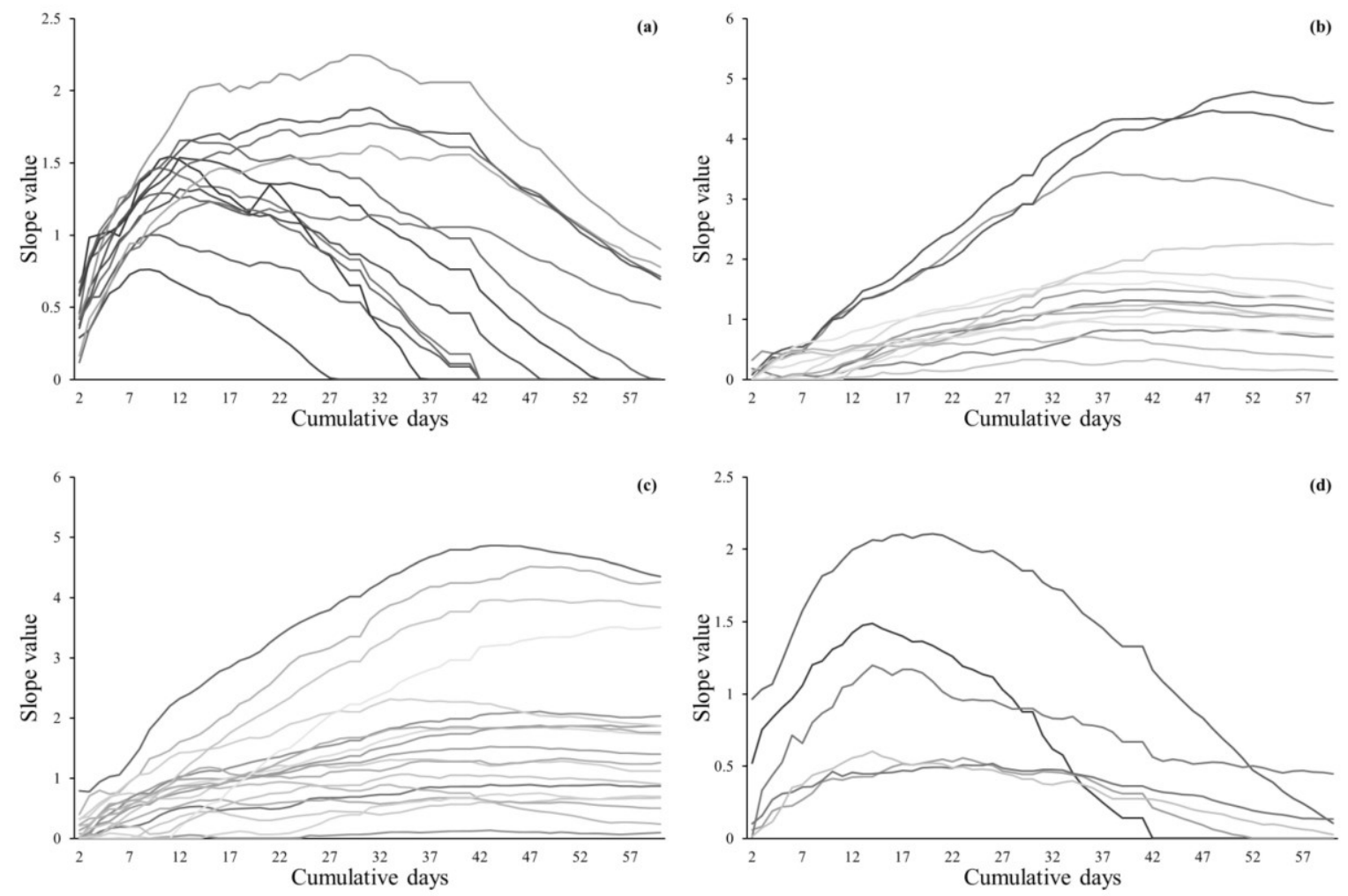

Fig. 4. The scatterplot between $\mathrm{R}^{2}$ and slope values in the different river types from Chl- $a$ regressed against CDSR for each cumulative day. (a) Danube, (b) Tisza, (c) Potamal, and (d) Rithral. Dots refer individual models, red dots indicates non-significant, while green ones indicates significant models at $\mathrm{p}<0.05$. 

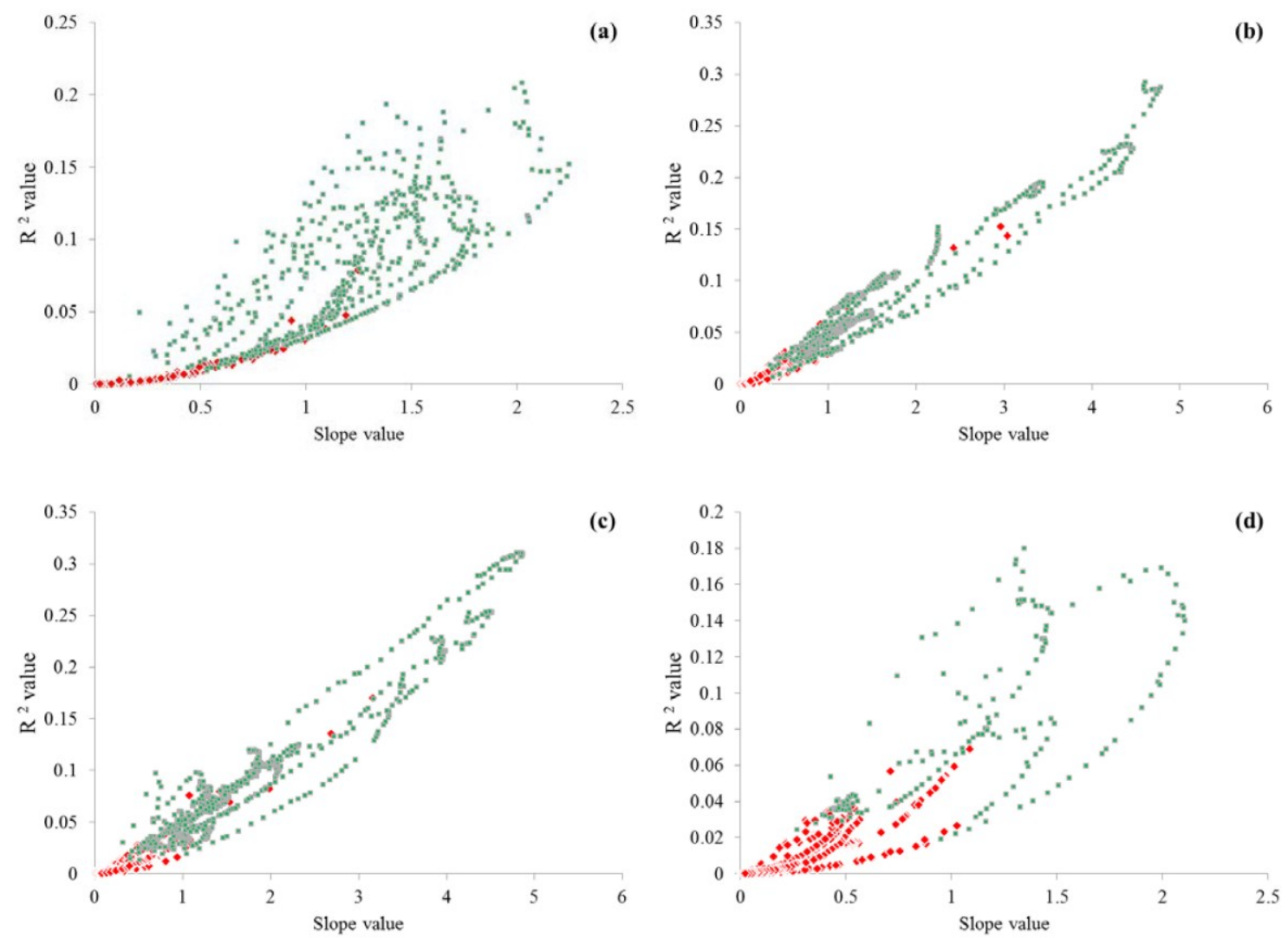

Fig. 5. Three-dimensional plots of the slope for Chl- $a$ regressed against CDSR in the light of the cumulative time period studied and the water residence time (WRT) in the different river types: (a) Danube, (b) Tisza, (c) Potamal, and (d) Rhitral 
(a)
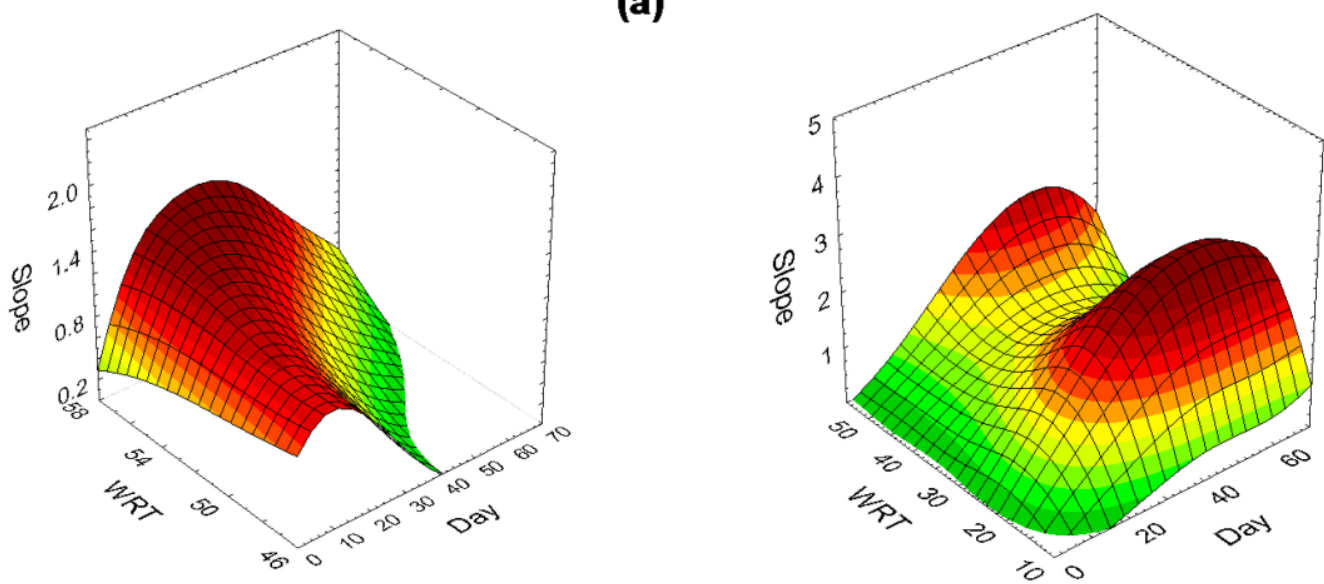

(b)

(c)

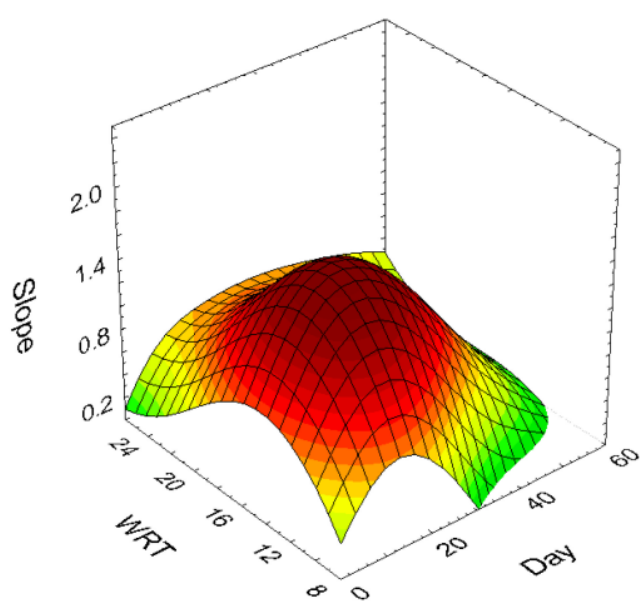

(d)

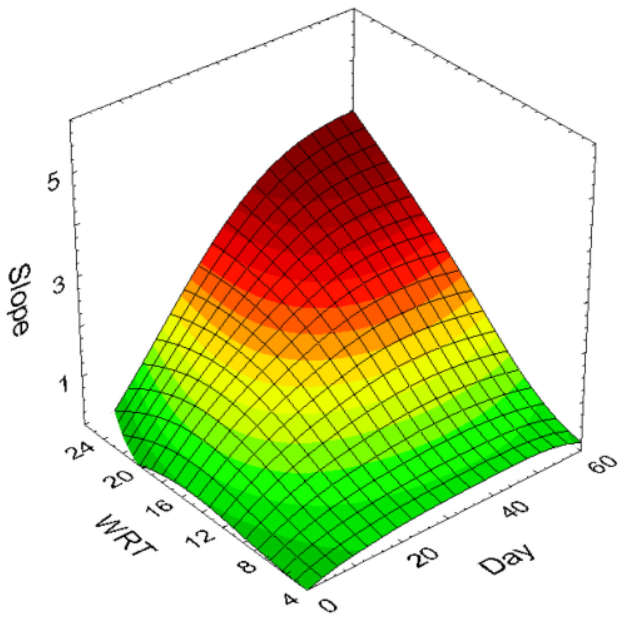

Table 1.

$1-60^{\text {th }}$ Model
dependent variable
$\left(\right.$ Y axis for Plot $\left.1-60^{\text {th }}\right)$

$1^{\text {st) }}$ Model

$2^{\text {nd }}$ Model

$\rightarrow$

$60^{\text {th }}$ Model

predictor

predictor

predictor variable

variable

variable

(X axis for Plot 60)

(X axis for Plot 1$) \quad$ (X axis for Plot 2 )

\begin{tabular}{|c|c|c|c|c|c|c|}
\hline Code of & Sampling site & Chl- $a\left(\mu \mathrm{L}^{-1}\right)$ & Date of & DSR 1 day earlier & Sum of DSR $1+2 \rightarrow$ & Sum of DSR \\
\hline measurements & code & & sampling & $\left(\mathrm{MJ} \mathrm{m}^{-2}\right)$ & days earlier (MJ & $1+2+3 \ldots \ldots+60$ \\
\hline from 1 to & $\mathrm{N}=91$ & & & & $\mathrm{~m}^{-2}$ ) & days earlier (MJ \\
\hline
\end{tabular}


$\mathrm{N}=13044$

$m^{-2}$ )

\begin{tabular}{|c|c|c|c|c|c|c|c|}
\hline 1 & Site $\mathrm{A}$ & 17 & 05.07 .2001 & 27 & 50 & $\rightarrow$ & 1115 \\
\hline 2 & Site $A$ & 23 & 06.08.2001 & 7 & 22 & $\rightarrow$ & 1225 \\
\hline 3 & Site A & 60 & 07.09.2001 & 18 & 33 & $\rightarrow$ & 890 \\
\hline - & & - & - & - & - & $\rightarrow$ & - \\
\hline - & & - & - & - & - & $\rightarrow$ & - \\
\hline - & & - & • & - & - & $\rightarrow$ & • \\
\hline $\mathrm{N}$ & Site $\mathrm{N}$ & 63 & 09.09.2007 & 21 & 43 & $\rightarrow$ & 1370 \\
\hline
\end{tabular}


